\title{
An Overview of Used-Products Remanufacturing
}

\author{
Magdalene Andrew-Munot ${ }^{1}$, Raafat N Ibrahim ${ }^{2}$ \& Ervina Junaidi ${ }^{1}$ \\ ${ }^{1}$ Department of Mechanical \& Manufacturing Engineering, Faculty of Engineering, Universiti Malaysia Sarawak, \\ Sarawak, Malaysia \\ ${ }^{2}$ Department of Mechanical and Aerospace Engineering, Faculty of Engineering, Monash University, Australia \\ Correspondence: Magdalene Andrew-Munot, Department of Mechanical \& Manufacturing Engineering, Faculty \\ of Engineering, Universiti Malaysia Sarawak, 94300 Kota Samarahan Sarawak, Malaysia. Tel: 60-8258-3300. \\ E-mail: ammagdal@feng.unimas.my
}

Received: September 27, 2014 Accepted: November 17, 2014 Online Published: January 26, 2015

doi:10.5539/mer.v5n1p12 URL: http://dx.doi.org/10.5539/mer.v5n1p12

\begin{abstract}
Remanufacturing is an important production activity, which is mainly driven by the increasingly strict environmental regulations imposed by governmental bodies, growing customers' awareness of green environment and potential economic benefits of remanufacturing. In this paper, the key motivating factors for companies to engage in remanufacturing program are examined. The major sources for acquiring used-products and the subsequent markets for selling remanufactured products are also examined. More importantly, the generic-key remanufacturing processes are examined and the corresponding unique characteristics are highlighted. Four examples of remanufacturing process of different products are presented to demonstrate that exact number and sequence of remanufacturing process largely depended on the type of product being remanufactured. In sum, this paper presents an overview of used-products remanufacturing, which in many ways would benefit the general public, environment, manufacturers/remanufacturers, as well as researchers.
\end{abstract}

Keywords: used-products, remanufacturing, product recovery

\section{Introduction}

Recently, remanufacture of used/worn-out/broken products has become a vital part of production activity in many companies (Ferrer \& Swaminathan, 2009; Schulz \& Ferretti, 2011). The automotive sector particularly has a strong and long history of remanufacturing (Seitz, 2007; Golinska, \& Kawa, 2011) where the alternator has the highest remanufacturing rate (Schau, Traverso, \& Finkbeiner, 2012). Remanufacturing is also gaining scientific significance in a variety of industries that include single use-devices for hospitals, such as wheelchairs and hearing aids (Srivastava, 2004) cellular phones (Guide Jr, Jayaraman, \& Linton, 2003b) and truck tyres (Lebreton \& Tuma, 2006). The diverse nature of remanufactured products together with different degrees of remanufacturing efforts creates a variety of applications (Zikopoulos, 2012). At one end is the direct re-use of slightly used commercial used-products, to the high-touch remanufacture of expensive modules, which are reassembled in complex new products, at the other end.

Remanufacture of used/worn-out/broken products (remanufacturing), refers to an industrial process in which used/worn-out/broken products (henceforth called used-products) are transformed into "new products" (Lund, 1984b). Hereafter, these "new products" are referred to as remanufactured products to distinguish them from a completely new product. Generally, any manufactured products or devices can be remanufactured, provided that these are discarded used-products with lower materials and components reprocessing costs compared to the market value of remanufactured items (Lund, 1984b). Also as outlined by Hauser and Lund (2003), used-products must be; (i) durable products, (ii) products that fails functionally, (iii) standardized products with interchangeable parts, (iv) products with high remaining value-added, (v) products with low acquisition cost, (vi) products with stable technology, and (vii) customer awareness of the remanufactured version.

Remanufacturing process could be sometimes confused with other similar activities such as repairing, refurbishing and reconditioning. Repaired, refurbished and reconditioned products are very close to remanufactured ones and these terms can regularly be considered synonymous with each other (Ijomah, McMahon, Hammond, \& Newman, 2007b). Though these terms have similarities, however in term of functionality and performance, the weightage and meanings are different. For example, repairing is described as corrections of specified faults in a product; 
when repaired products have warranties, the warranty does not cover the whole product but only on the component that has been replaced. In refurbishing, a used-product is cleaned up, tested, repackaged and made available for resale. A refurbished product has some nonworking parts that are replaced to restore the product to working condition, with warranty less than that of a new product. For reconditioning, a used-product is cleaned up and tested extensively with possible repair before repackaged for resale at a satisfactory working condition, with warranty less than that of a newly manufactured equivalent, in which the warranty applies to all major wearing parts. Finally, the term recycling describes the processing of used material into new products through discarding used materials into production of different or same product.

This paper aims is to provide the general public, potential remanufacturers, as well as researchers with valuable insights into remanufacturing program by examining remanufacturing activities and identifying major opportunities and concerns. The remainder of this paper begins in Section 2, which examines the three major motivating factors for remanufacturing. The next section (Section 3), examines the sources for acquiring used-products and markets for selling remanufactured products. Section 4 examines the different types of remanufacturing companies. Section 5 presents the generic remanufacturing process and four examples of real-industry remanufacturing process for different products. Finally in Section 6, the concluding remarks on the overview of used-products remanufacture are presented.

\section{Motivations and Benefits of Remanufacturing}

The three major factors that are responsible for motivating companies to engage in remanufacturing are product take-back legislations, customers' awareness of green environment and economic benefit.

Product Take-Back Legislations - These emerging legislations imposed by governmental bodies force companies to extend their manufacturers' responsibility to include products that have been used and retired. This in turn, forces companies to design products and production process that would make it possible to recover used-products through remanufacturing activity. In Europe, for example, the directive on waste electrical and electronic equipment (Directive/2002/96/EC) states that "Where appropriate, priority should be given to the reuse of waste electrical and electronic equipment (WEEE) and its components, subassemblies and consumables. Where reuse is not preferable, all WEEE collected separately should be sent for recovery, in the course of which a high level of recycling and recovery should be achieved. In addition, producers should be encouraged to integrate recycled material in new equipment". Similarly, the directive on legislation of end-of-life vehicle (European Council Directive 2000/53/EC 2000) has forced the European automobile manufacturers to assume full responsibility for disposal of cars manufactured from 2002 onwards with no cost to the final owners. The directive also states that "the requirements for dismantling, reuse and recycling of end-of life vehicles and their components should be integrated in the design and production of new vehicles". These strict environmental regulations results in greenhouse gas emission from remanufacturing that is about $90 \%$ less than the manufacturing of new product; a study done on remanufacture of compressors (Gamage, Ijomah, \& Windmill, 2013).

Customers' awareness of green environment - Customers' are becoming aware of the implication of disposing used-products on the environment. For instance, more consumers are procuring products from manufacturers who take back their products after the end of the products' useful life (Gungor \& Gupta, 1999). In another report by Ginsberg and Bloom (2004) the percentage of consumers who are interested in some form of green products are between $15 \%$ and $46 \%$. For the manufacturers, taking back and reprocessing their used-products in an environmentally-friendly manner creates the opportunity to boost the value of their products. For example, Fuji Xerox Australia (2007a) has taken the initiative to be one of the pioneering companies that implements remanufacturing program for printers and copier parts. In 2006, for example, such remanufacturing practice has saved the company approximately $\$ 13$ million and created revenue of $\$ 5.4 \mathrm{~m}$ in exports. Similarly, Hewlett-Packard, HP (2014) also embraces the green environment culture through recycling programs, which help to reduce the environmental impact of the companies' activities. In a comparable effort in 2012, IBM (2014) worldwide product end-of-life management operations processed 36,100 metric tons of end-of-life products for reuse or recycling, sending only 0.3 percent of the total to landfills or to incineration facilities for treatment.

Economic Benefit - Remanufacture of-used products incurred cost that is typically $40 \%-65 \%$ less that those incurred in the manufacture of new products (Dowlatshahi, 2000; Giuntini \& Gaudette, 2003) and remanufactured products are typically sold off at $45 \%$ - 65\% of the prices of new products (Lund \& Hausner, 2003). This results from the availability of raw materials (recovered components), which are cheaper than those newly manufactured components; recovered components do not have to be redesigned and ordered from suppliers. As reported in a publication by the All-Party Parliamentary Sustainable Resource Group (2014) and shown in Figure 1, the economic advantage of remanufacturing is vast. For producing remanufactured products (sold at $20 \%$ discount), the input costs 
is significantly lower than the input costs for manufacturing new products from virgin resources; the same case applies for the remanufacture of lease products (e.g. leased Ricoh photocopiers). Also, as shown in the figure 1, remanufacture of leased products yielded the highest gross profit when compared to the gross profit of manufacture of products from virgin resources. From the remanufacturers' perspective, they benefited economically from the significant discounts for the remanufactured products with the same warranty and quality ( $\mathrm{Lu}, \mathrm{Goh}, \mathrm{Garg} \&$ Souza, 2014). It is also well recognized that reuse of components in the production of subsequent product generations, results in cost savings (Bhattacharya, Guide Jr., \& Van Wassenhove, 2006). In terms of energy and materials consumption, remanufacture of used-products contribute to less usage than that is needed to manufacture new products (Kim, Skerlos, Severengiz, \& Seliger, 2009; Boustani, Sahni, Graves \& Gutowski, 2010; Warsen, Laumer, \& Momberg, 2011; Sundin \& Lee, 2012). To give an example, as reported in Kim et. al., (2009), remanufacture of automotive engine can reduced metal consumption by 7,650 tonnes, conserved energy as much as 16 million $\mathrm{kW} \mathrm{h}$ and decreased emission of about 11,300 to 15,300 tonnes $\mathrm{CO} 2$ equivalent (CO2eq).

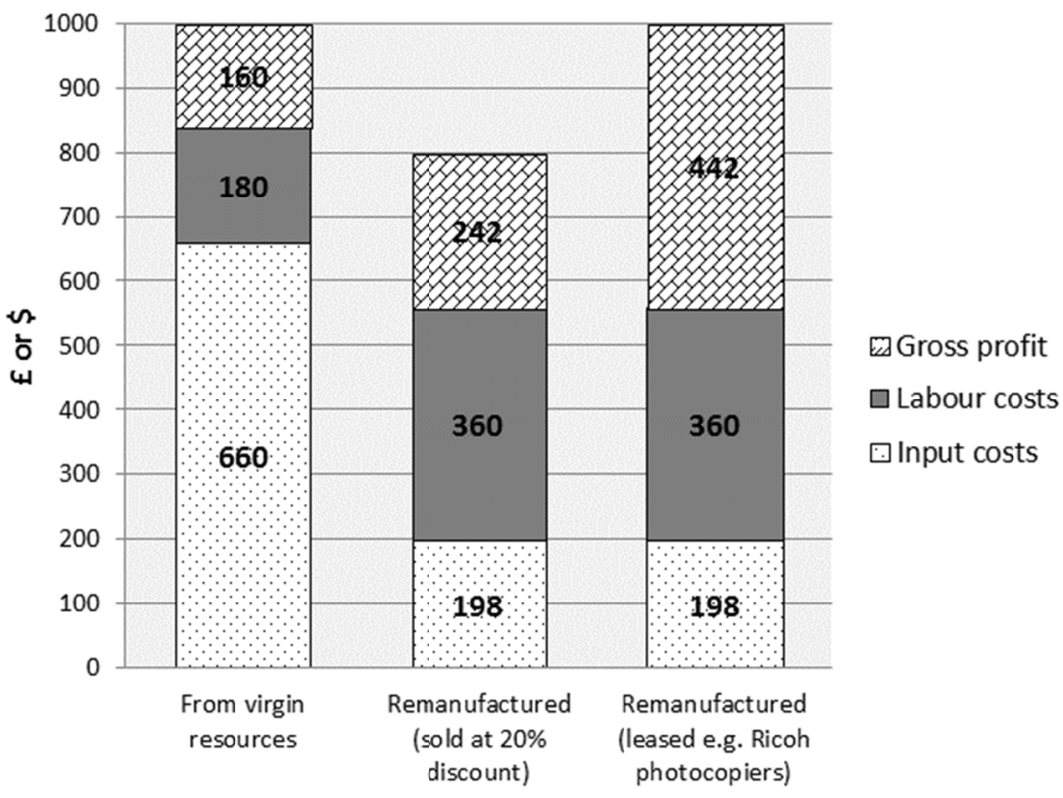

Figure 1. Potential Economic Benefits of Remanufacturing (reproduced from a report retrieved from http://www.policyconnect.org.uk/apsrg/sites/site_apsrg/files/apsrg___remanufacturing_report.pdf)

Until recently, companies have considered environmental regulations and consumers' awareness as additional operational cost, rather than opportunities to generate alternative profit and boost corporate image. However, with the increasing pressure to become environmentally responsible and sourcing for inexpensive raw materials, more companies are considering remanufacturing as a strategy to generate profit, boost company image and maintain competitiveness.

\section{Sources of Used-Products and Market for Remanufactured Products}

The two major types of product remanufactured are used capital goods and used consumer goods (Dobos \& Floriska, 2008). These used-products are acquired either from the waste-stream or market-stream (Guide \& Wassenhove, 2001; Jayaraman, 2006). The waste-stream generates used-products that are no longer useful, which includes vehicles that are damaged during accidents and sent to wrecking facilities; or malfunctioned electrical home appliances that are sent to third-party products recovery facilities. As such, the waste-stream generates used-products with uncontrollable quality and quantity (Ghoreishi, Jakiela, \& Nekouzadeh, 2011). The market-stream generates used-products that are still useful but are no longer needed by the owners. For example, old models of mobile phone are traded-in for new models with advanced and sophisticated features. Thus, the quality conditions and quantity of these used-products are controllable by giving the appropriate amount and type of incentives for returning the used-products. Also, as reported by Guide and Wassenhove (2001), the quality of used-products could be controlled by having a system to grade the used-products based on their condition and age and pays the financial incentives accordingly. Alternatively, as demonstrated in a study by Kumar, Liou, Balakrishnan \& Kumar (2013) the use of radio-frequency identification (RFID) technology could effectively 
improve visibility of data on the quality conditions of used-products, which consequently improve inventory control and operational efficiency at collection, disassembly and refurbishing centres. Irrespective of their sources, the quantity of used-products available for remanufacturing is bound by the quantity of new products sold in the previous periods (Esenduran, Emahlıo glu-Ziya, \& Swaminathan, 2012).

From the suppliers perspective, there are five different ways to acquire used-products from the suppliers, namely Direct-Order, Reman-Contract, Deposit-Based, Credit-Based and Buy-Back (Sundin \& Dunbäck, 2013). In direct-order, the customers are the suppliers themselves, and they send their used-products to the remanufacturer. The remanufactured products would be sent back to the customers/suppliers. This is typical for complex products such as engines and other end user items. Similarly, for reman-contract, the customers are the suppliers themselves, who gives an order to remanufacture the used-products. In this case, there is a closer collaboration between the remanufacturer and customers/suppliers, it usually invoves greater quantities of used-products and common towards original equipment manufacturers (OEM). The deposit-based used-products are common in the automotive industry; this requires the customers to send used-products (e.g. brake calipers) that are similar to new parts that they needed. Comparable to the Direct-Order and Contract-Reman, in the credit-based, the customers are also the suppliers. In this situation, for customers who send their used-products, credits are given to them, which could be utilized as a discount for buying remanufactured products. Finally, the Buy-Back used-products are often obtained from the used-product brokers, scrap yards or end-users.

In the world, the U.S. market for remanufactured goods is the largest, where the production of remanufactured goods increased from $\$ 37.3$ billion (in 2009) to $\$ 43.5$ billion in 2011 (United States International Trade Commission, 2012). The types of these remanufactured goods are from production, from import and for export (Table 1). Specifically, the top three industry that contribute to these remanufactured goods are Aerospace, heavy-duty and off-road (HDOR) equipment and motor vehicle parts (Table 2).

Table 1. Remanufactured goods: U.S. market (apparent consumption) for remanufactured goods, 2009 - 2011 2011 (reproduced from (United States International Trade Commission, 2012))

\begin{tabular}{lcccc}
\hline Type & 2009 & 2010 & 2011 & \% change, 2009 - 2011 \\
\hline \multicolumn{5}{c}{ Thousands \$ } \\
\hline Production & $37,280,784$ & $39,882,004$ & $43,000,144$ & 15.3 \\
Imports & $6,256,042$ & $9,508,060$ & $10,263,056$ & 64.1 \\
Exports & $7,502,991$ & $8,805,067$ & $11,735,665$ & 56.4 \\
\cline { 2 - 5 } U.S. apparent consumption & $36,033,835$ & $40,584,997$ & $41,527,535$ & 15.2 \\
\hline
\end{tabular}

Note: Totals may not sum due to rounding.

Table 2. Remanufactured goods: production of remanufactured goods by sector, 2009 - 2011(reproduced from (United States International Trade Commission, 2012))

\begin{tabular}{lcccc}
\hline Sector & 2009 & 2010 & 2011 & \% change, 2009 - 2011 \\
\hline \multicolumn{5}{c}{ Thousands \$ } \\
\hline Aerospace & $11,691,316$ & $12,677,916$ & $13,045,513$ & 11.6 \\
HDOR equipment & $5,152,938$ & $6,244,302$ & $7,770,586$ & 50.8 \\
Motor vehicle parts & $7,018,303$ & $6,969,823$ & $6,211,838$ & -11.5 \\
Machinery & $4,059,570$ & $4,774,291$ & $5,795,105$ & 42.8 \\
IT products & $2,709,170$ & $2,592,831$ & $2,681,603$ & -1.0 \\
Medical devices & $1,307,588$ & $1,367,739$ & $1,463,313$ & 11.9 \\
Retreaded tires & $1,038,679$ & $1,188,315$ & $1,399,088$ & 34.7 \\
Consumer products & 557,612 & 567,320 & 659,175 & 18.2 \\
All other & $3,745,608$ & $3,499,468$ & $3,973,923$ & 6.1 \\
Total & $37,280,784$ & $39,882,004$ & $43,000,144$ & 15.3
\end{tabular}

Note: Totals may not sum due to rounding.

${ }^{a}$ The electrical apparatus, locomotive, office furniture, and restaurant equipment remanufacturing sectors. 
Generally, remanufactured products are sold either in the primary-market or secondary-market. Within the primary product market, remanufactured products are perfect substitutes for new products (Souza \& Ketzenberg, 2002). This refers to original equipment manufacturer (OEM) used-products, which are remanufactured to a quality standard that is as good as new at the OEM's remanufacturing facility. For example Katun Corporation (Katun Corporation, 2014), one of the world's leading providers of OEM-compatible imaging supplies, photoreceptors, and parts for copiers, printers, MFPs and other imaging equipment, remanufacturers cartridges for use in HP Color Printers/MFP's. For this company, ensuring customer satisfaction means offering the highest and most consistent remanufactured toner cartridge quality possible. The remanufactured products are sold in the same market as the new products, at a cheaper price than the new ones (Ferrer \& Swaminathan, 2009). By selling remanufactured products together with new ones, companies area able to better segment their demand and seize sales to the "low-end" customers, who will not purchase the new product. This requires that the price and quantity of remanufactured products are properly selected (Ovchinikov, 2011). These remanufactured products could also be sold at the same price as newly manufactured products (Gallo, Romano, \& Santillo, 2012). However, as reported in (Atasu, Guide, \& Van Wassenhove, 2010) there are concerns that selling remanufactured products in the same market with new products might cannibalized the sales of new products.

For the secondary product market, remanufactured products are popular amongst customers who may have financial restrictions. For example, remanufactured multifunctional digital copiers or multi-function peripherals (MFPs) are sold to customers who are satisfied with the cheaper and lower-level functions MFPs (Chang, Bae, Yi, 2013). Furthermore, as reported in Osibanjo and Nnrom (2008), it is estimated that the demand for remanufactured mobile phones in Nigeria is still higher than their availability. For the secondary-market, remanufactured products are usually produced by third-party remanufacturers who harvest the economic benefits of remanufacturing. In this case, usually, the remanufactured products (e.g., computer systems, auto components, and office equipment) have a lower quality standard and price than newly manufactured products (Ayres, Ferrer, \& van Leynseele, 1997; Ferrer, 1997). The boundaries of the primary and secondary markets are clearly separated in the case of remanufactured and new mobile phones. However, in the case of remanufactured and new automotive components, these two markets overlap (Gallo, et. al., 2012).

\section{Types of remanufacturer}

Remanufacturing could either be carried out by original equipment manufacturer (OEM) remanufacturers, contract remanufacturers or independent remanufacturers. For OEM remanufacturers, remanufacturing could co-exist with the normal manufacturing activity, in which resources could either be dedicated to each activity or shared amongst the two activities. For the OEM remanufacturers, remanufacturing activity is an alternative way to generate extra income (from the production of remanufactured spare-parts and products) and obtain low cost raw materials. Most importantly, by remanufacturing its own products, OEM manufacturers could avoid competition from independent remanufacturers (Gutowski, Sahni, Boustani, \& Graves, 2011). Some examples of OEM remanufacturers are (i) Fuji Xerox for parts and sub-assemblies from photocopier (Fuji Xerox Australia, 2007a), (ii) Alpha1 Technologies for heads and cameras (AlphalTechnologies, 2014), (iii) Robert Bosch Tool for alternators and starters (Robert Bosch Tool Corporation, 2014), and (iv) Hewlett-Packard for inkjet printers (Hewlett-Packard, 2014).

For both contract and independent remanufacturers, remanufacturing activity is an alternative source for generating profit. Contract remanufacturers are companies that are contracted by OEM to remanufacture their used-products; for example Hewlett-Packard's used-printers are remanufactured in a network of hardware recovery centers (Kumar, Guide Jr, \& Van Wassenhove, 2002). In this case Hewlett-Packard carefully protect their intellectual capital and brand name through a contractual agreements, as well as enforcing their quality standards. Independent remanufacturers are companies that realize the economic benefits of remanufacturing, and thus would remanufacture any type of used-products, as long as there are markets for them.

Even though remanufacturing market is dominated by OEMs and contract remanufacturers, the majority of the remanufacturers are independent small-scale operators (Matsumoto \& Ijomah, 2013). However, the OEM remanufacturers with their available resources, would be able to effectively remanufacture their own used-products compared to the independent remanufacturers. The resources as reported in Boustani (2010) are (i) full knowledge of the durability, reliability, replacement parts, and proper disassembly methodologies of their own used-products, (ii) established network for the supply and distribution of the remanufactured products, (iii) established relationship with suppliers of parts and materials, (iv) knowledge of customers use patterns, psychology and potential reasons for using remanufactured products, (v) market power, established manufacturing platform, and available workforce to venture into remanufacturing practices. 


\section{Remanufacturing Process}

In general, remanufacturing process consists of four generic-key process, where different activity takes place at each process (Figure 1). The exact number of process and sequence depend on the nature of used-products being remanufactured (Ilgin \& Gupta, 2012). The four process can be further expanded to twelve processes, as reported in Boustani (2010) to include (i) warehouse of incoming used-products, parts, and outgoing remanufactured products, (ii) sorting of incoming used-products, (iii) cleaning of used-products, (iv) disassembly of used-products and subassemblies, (v) inspection of used-products, subassemblies, and parts, (vi) cleaning of specific parts and subassemblies, (vii) repair or renewal of parts, (viii) testing of parts and subassemblies, (ix) reassembly of parts, subassemblies and products, $(\mathrm{x})$ testing of subassemblies and finished products, (xi) packing, and (xii) shipping.

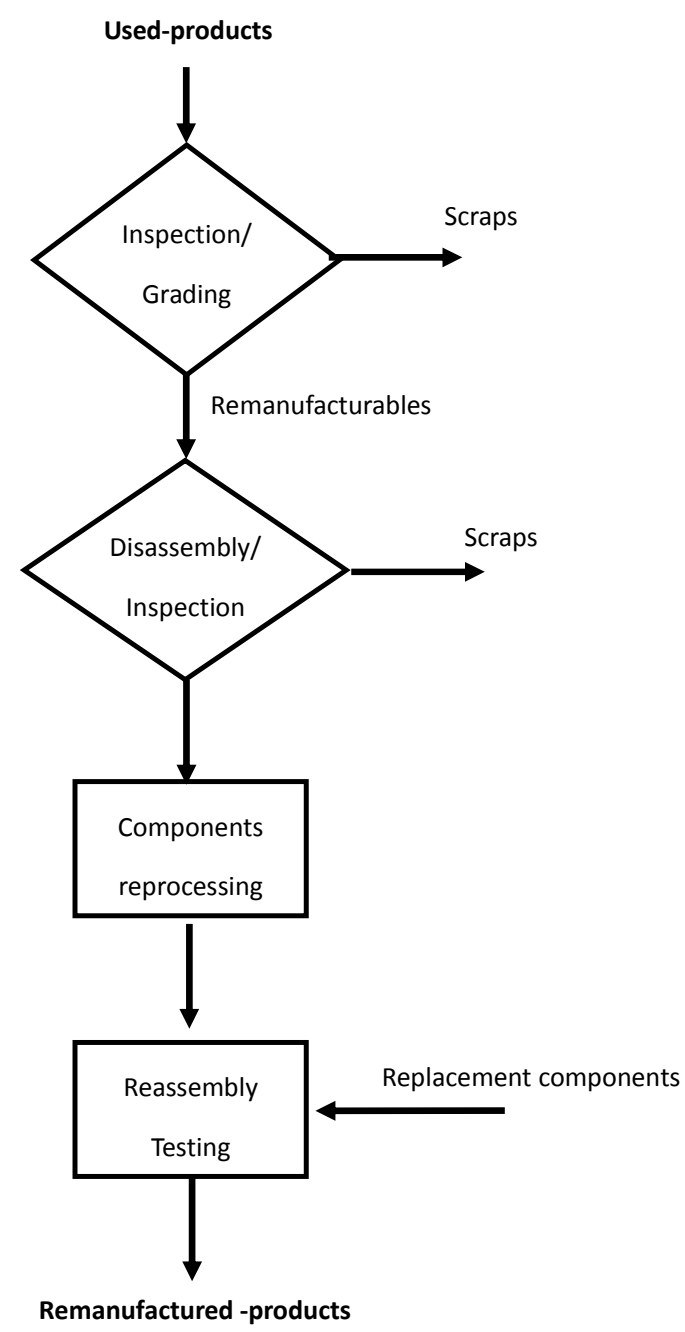

Figure 2. Generic Remanufacturing Process [constructed based on the description provided in Lund (1984a)]

Inspection/Grading process - During this process, used-products are inspected to assess their remanufacturability status, which could either be remanufacturables or scraps. Unlike, manufacturing, remanufacturing requires $100 \%$ inspection of used-products (Errington \& Childe, 2013). This process usually involves complete visual inspection, where inspection times are identical for the same type of used-products that originate from the same source (e.g. used-cellular phones from the market stream). On the other hand, the waste-stream used-products with high variability of quality conditions require different inspection times for each unit. Scraps are either disposed off or sold to scrap brokers, whereas remanufacturables are sent to the disassembly/inspection process.

The inspection yield (fraction of used-products graded as remanufacturables) could vary from one batch to another due to the uncertain quality conditions of used-products. Remanufacturables could be further classified into several quality groups, in which the best quality group is given the highest priority to remanufacture (Aras, Boyaci, 
\& Verter, 2004; Aras, Verter, \& Boyaci, 2006). The waste-stream used-products with high variability of quality conditions, would yield more quality groups than the market-stream.

Disassembly/inspection - Each unit of remanufacturable is disassembled into its corresponding modules, which are further disassembled into their constituent components. This process usually involves general purpose tools such as power drill, although in some cases, robot arms might be necessary for disassembly of complex products (Steinhilper, 1998) or hazardous parts (Zussman \& Seliger, 1999). Despite the quality groups and source, disassembly time for the same type of remanufacturables would be identical. This time mainly depends on the product structure complexity, where remanufacturables with a simple product structure, would require a shorter disassembly time than remanufacturables with a more complex product structure.

Depending on the product structure and volume, disassembly of remanufacturables and inspection of the constituent components could either take place simultaneously or sequentially. For high volume of remanufacturables with simple product structures, disassembly and inspection process could take place simultaneously. Likewise, for low volume of remanufacturables with complex product structure, disassembly and inspection process could takes plane simultaneously. By contrast, for high volume of remanufacturables with complex product structure, disassembly and inspection process usually take place sequentially in a two-stage disassembly line (Steinhilper, 1998).

During inspection, each unit of constituent component could either be classified as remanufacturable or scrap. Scrap components are replaced with newly manufactured components, which are ordered either from the internal production lines (for OEMs remanufacturers) or external sources (for contract or independent remanufacturers). Replacement components are very critical, particurly for a remanufacture-to-order strategy, where customers send their used-products for remanufacture and get the same item back.

The fraction remanufacturable components (i.e. disassembly yield), might differs from one batch to another; this results from the uncertain quality conditions of remanufacturables. Remanufacturable components could be further classified into different quality groups, where the best component quality group should be given the highest priority to remanufacture. The waste-stream remanufacturables would result in more quality component groups than the market-stream remanufacturables.

Irrespective of the product structure, the product design would also affect the disassembly yield of constituent components (Ferrer, 2001). Products that are originally design for disassembly would generate a higher disassembly yields than those that are not originally designed for disassembly because of the damaged during disassembly. Thus, it is important to integrate product design in the product development process in order to reduce damaged components (Ijomah, McMahon, Hammond, \& Newman, 2007a; Ijomah, 2009; Barquet, Rozenfeld \& Forcellini, 2013).

Components reprocessing - This process typically involves cleaning, repairing (e.g. machining worn-out holes) and surface finishing (Sundin, \& Bras, 2005). The actual number of reprocessesing steps and corresponding time depend on the component quality group. For example, the best component quality group would perhaps need a simple process (eg cleaning and surface finishing) and short reprocessing time. By contrast, the worst component quality group probably requires a more complex reprocessing steps (eg cleaning, repairing and surface finishing) and longer reprocessing time. For complex component design, multiple repair steps, such as welding and trimming might be necessary in order to restore the components to their original condition. Equally, for some components such as bulb, electrical wire or cellular phone casing, there is no repair process required because these components are merely replaced with new ones.

Reassembly/testing - This process typically involves general purpose tools to reassemble the reprocessed components into remanufactured products. In some cases, it is necessary to use robot arms to reassemble constituent components into remanufactured products with complex structure. Finally, testing ensures that the assembled products, i.e. remanufactured products meet their specified function.

As shown earlier in Figure 1, remanufacturing process includes inspection/grading, disassembly/inspection, component reprocessing and reassembly/testing. However, the exact number of process and sequence depend largely on the types of used-products being remanufactured. This can be observed in Figures 3 - 6, which illustrate examples of remanufacturing process of four different products. Figure 2 shows the remanufacturing process of photocopiers, figure 3 shows the remanufacturing process of automotive engines, figure 4 shows the remanufacturing process of ink cartridges and figure 5 shows the remanufacturing process of medical devices. 


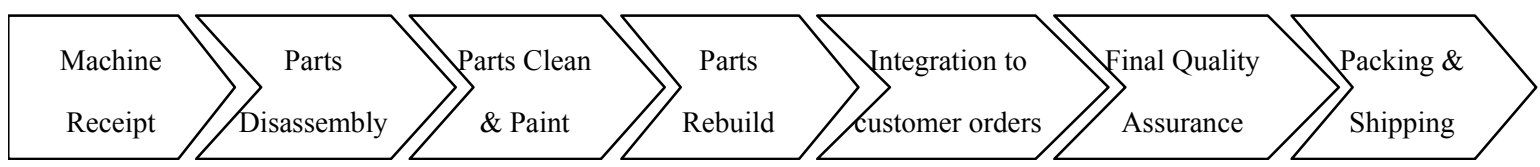

Figure 3. Remanufacturing process of photocopiers, Xerox UK (King, Miemczyk \& Buffon, 2006)

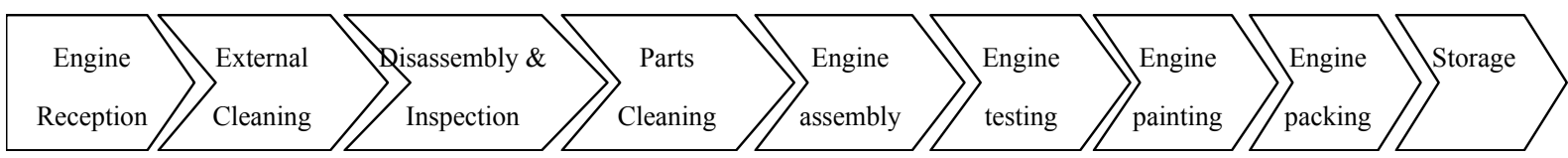

Figure 4. Remanufacturing process of automotive engines [constructed based on information obtain from $\mathrm{mti}$ (2014)

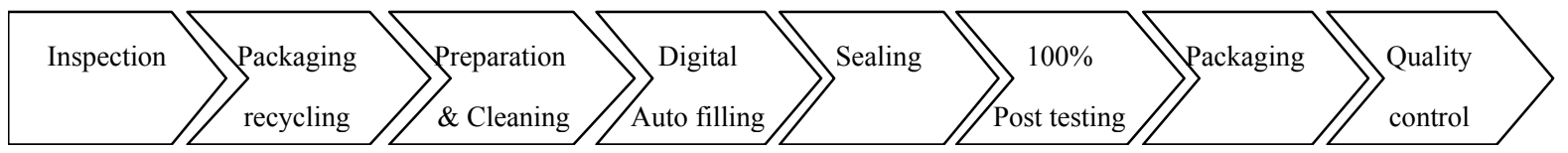

Figure 5. Remanufacturing process of ink cartridges (constructed based on information obtain from Clover Technologies Group (2014)

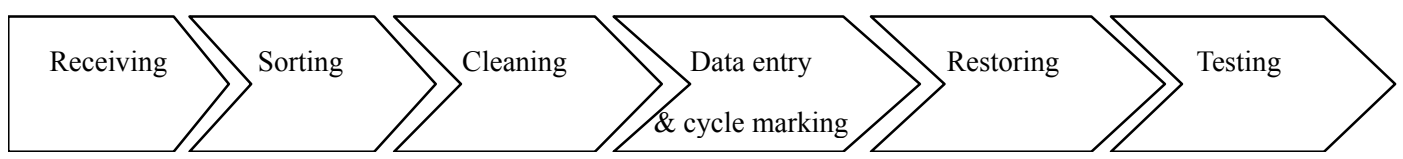

Figure 6. Remanufacturing process of medical devices (constructed based on information obtained from Stryker Sustainability Solutions (2014)

\section{Concluding Remarks}

Until recently, not many companies engaged in remanufacturing activities. Nonetheless, with the increasingly strict environmental regulations, growing consumers' awareness of green environment and potential economic benefits, more companies are involve in remanufacturing programs. This article makes contributes in the following ways. Firstly, this article highlights the key factors that motivate companies to engage in remanufacturing activities. Secondly, this article identifies the potential sources for acquiring used-products and the markets for selling remanufactured products. Thirdly, this article highlights the generic-key remanufacturing process to be inspection/grading, disassembly, components reprocessing and reassembly.. Fourthly, this article highlights four unique remanufacturing characteristics that are uncertain quality conditions of used-products, variable inspection-yields of used-products, variable disassembly-yield of constituent components and variable reprocessing efforts of constituent components. Finally, this article illustrates with example that the exact number of process $\&$ sequence depended on the type of used-product being remanufactured. In short, remanufacturing program, despite its fundamental requirements and unique characteristics, would in many ways benefit the general public, environment, manufacturers/remanufacturers and researchers.

\section{Acknowledgment}

The authors would like to acknowledge Universiti Malaysia Sarawak (UNIMAS) for giving financial support towards this project.

\section{References}

All-Party Parliamentary Sustainable Resource Group. (2014). Remanufacturing: Towards a Resource Efficient Economy: report from the three-month inquiry into the need for UK government to improve UK's remanufacturing. Retrieved from http://www.policyconnect.org.uk/apsrg/sites/site_apsrg/files/apsrg_-remanufacturing_report.pdf

Alpha1Technolgies. (2014). Information retrieved from http://alpha1technologies.com/remanufactured-headsand-cameras 
Aras, N., Boyaci, T., \& Verter, V. (2004). The effect of categorizing returned products in remanufacturing. IIE Transactions, 36(4), 319-331. http://dx.doi.org/10.1080/07408170490279561

Aras, N., Verter, V., \& Boyaci, T. (2006). Coordination and priority decisions in hybrid manufacturing/remanufacturing systems. Production and Operations Management, 15(4), 528-543. http://dx.doi.org/10.1111/j.1937-5956.2006.tb00161.x

Atasu, A., V. Daniel R. Guide, Jr., \& Van Wassenhove, L. N. (2010). So what if remanufacturing cannibalizes my new product sales?. California Management Review, 52(2).

Ayres, R., Ferrer, G., \& Van Leyseele, T. (1997). Eco-efficiency, asset recovery and remanufacturing. European Management Journal, 15(5), 447-574. http://dx.doi.org10.1016/S0263-2373(97)00035-2

Barquet, A. P., Rozenfeld, H., \& Forcellini, F. A. (2013). An integrated approach to remanufacturing: model of a remanufacturing system. Journal of Remanufacturing, 3(1). http://dx.doi.org/10.1186/2210-4690-3-1

Bhattacharya, S., Guide Jr., V. D. R., \& Van Wassenhove, L. N. (2006). Optimal order quantities with remanufacturing across new products generations. Production and Operations Management, 15(3), 421-431. http://dx.doi.org/ 10.1111/j.1937-5956.2006.tb00255.x

Boustani, A. (2010). Remanufacturing and Energy Savings. Master of Science Thesis

Boustani, A., Sahni, S., Graves, S. C., \& Gutowski, T. G. (2010). Appliance remanufacturing and life cycle energy and economic savings. In Sustainable Systems and Technology (ISSST) (pp. 1-6). 2010 IEEE International Symposium, Arlington, VA. http://dx.doi.org/10.1109/ISSST.2010.5507713

Chang, Y., Bae, J. H., \& Yi, H. C. (2013). Ultrasonic Cleaning of Used Plastic Parts for Remanufacturing of Multifunctional Digital Copier. International Journal Of Precision Engineering And Manufacturing, 14(6), 951-956. http://dx.doi.org/10.1007/s12541-013-0125-8

Clover Technologies Group. (2014). 8-Step Ink Cartridge Remanufacturing Process. Retrieved from $\mathrm{http} / / / \mathrm{www} . c l o v e r t e c h . c o m /$ eight-step-ink-cartridge-remanufacturing-process

Directive 2000/53/EC of the European Parliament and of the Council of 18 September 2000 on end-of life vehicles (Directive 2000/53/EC - the "ELV) (2000). Retrieved from http://ec.europa.eu/environment/ waste/elv_index.htm.

Directive 2002/96/EC of the European Parliament and of the Council of 27 January 2003 on waste electrical and electronic equipment (WEEE) (Directive/2002/96/EC). (2003). Retrieved from http://www.environ.ie/en/ Legislation/Environment/Waste/WEEE/FileDownLoad,613,en.pdf.

Dobos, I., \& Floriska, A. (2008). The efficiency of remanufacturing in a dynamic input-output model. Central European Journal of Operations Research, 16(3), 317-328. http://dx.doi.org/10.1007/s10100-008-0060-4.

Dowlatshahi, S. (2000). Developing a theory of reverse logistics. Interfaces, 30, 143-155. http://dx.doi.org/10. 1287/inte.30.3.143.11670

Errington, M., \& Childe, S. J. (2011). A business process model of inspection in remanufacturing. Journal of Remanufacturing, 3(7). http://dx.doi.org/ 10.1186/2210-4690-3-7.

Esenduran G., Emahlı־glu-Ziya, E., \& Swaminathan, J. M. (2012). Product Take-Back Legislation and Its Impact on Recycling and Remanufacturing Industries in T. Boone et al. (Eds.), Sustainable Supply Chains, 129. International Series in Operations Research \& Management Science, 174. http://dx.doi.org/10.1007/ 978-1-4419-6105-1

Ferrer, G. (1997). The Economics of Tire Remanufacturing. Resources, Conservation and Recycling, 19(4), 221-255. http://dx.doi.org/10.1016/S0921-3449(96)01181-0

Ferrer, G. (2001). On the Widget Remanufacturing Operation. European Journal of Operational Research, 135(2), 373-393. http://dx.doi.org/10.1016/S0377-2217(00)00318-0

Ferrer, G., \& Swaminathan, J. M. (2009). Managing New and Differentiated Remanufactured Products. European Journal of Operational Research. http://dx.doi.org/10.1016/j.ejor.2009.08.007.

FujiXerox, Australia (2007a). Information. Retrieved from http://www.fujixerox.com.au/about/eco_manufacturing.jsp

Gallo, M., Romano, E., \& Santillo, L. C. (2012). A Perspective on Remanufacturing Business: Issues and Opportunities. International Trade from Economic and Policy Perspective, 209. http://dx.doi.org/10.5772/2726. 
Gamage, J. R., Ijomah, W. L., \& Windmill, J. (2013). What makes cleaning a costly operation in remanufacturing? In G. Seliger (Ed.), Proceedings of the $11^{\text {th }}$ Global Conference on Sustainable Manufacturing - Innovative Solutions.

Ghoreishi, N., Jakiela, M. J., \& Nekouzadeh, A., (2011). A cost model for optimizing the take back phase of used product recovery. Journal of Remanufacturing, 1(1). http://dx.doi.org/ 10.1186/2210-4690-1-1.

Ginsberg, J. M., \& Bloom, P. (2004). Choosing the Right Green Manufacturing Strategy. MIT Sloan Management Review, 46(1), 79 - 84.

Giuntini, R., \& Gaudette, K. (2003). Remanufacturing: The next great opportunity for boosting US productivity. Business Horizons, 41-48. http://dx.doi.org/10.1016/S0007-6813(03)00087-9

Golinska, P., \& Kawa, A. (2011). Remanufacturing in automotive industry: Challenges and limitations. Journal of Industrial Engineering and Management, 4(3), 453-466. http://dx.doi.org/10.3926/jiem.2011.v4n3. p453-466

Guide Jr., V. D. R., \& Van Wassenhove, L. N. (2001). Managing product returns for remanufacturing. Production and Operations Management, 10(2), 142-155. http://dx.doi.org/10.1111/j.1937-5956.2001.tb00075.x.

Guide Jr., V. D. R., Jayaraman, V., \& Linton, J.D. (2003b). Building contingency planning for closed-loop supply chains with product recovery. Journal of Operations Management, 21(3), 259-279. http://dx.doi.org/10. 1016/S0272-6963(02)00110-9

Gungor, A., \& Gupta, S. M. (1999). Issues in environmentally conscious manufacturing and product recovery: a survey. Computers and Industrial Engineering, 36(4), 811-853. http://dx.doi.org/10.1016/S0360-8352(99) 00167-9.

Gutowski, T. G., Sahni, S., Boustani, A., \& Graves, S. C. (2011). Remanufacturing and energy savings. Environmental Science \& Technology, 45(10), 4540-4547. http://dx.doi.org/ 10.1021/es102598b.

Hauser, W., \& Lund, R. T. (2003). Remanufacturing: An American resource. Teaching materials on remanufacturing. Retrieved from http://www.bu.edu/reman/RemanSlides.pdf

Hewlett Packard. (2014). Retrieved from http://www8.hp.com/us/en/hp-information/environment/recycling -reuse.html\#.UyeltvmSx-5.

IBM. (2014). Information retrieved from http://www.ibm.com/ibm/environment/products/recycling.shtml

Ijomah, W. L. (2009). Addressing decision making for remanufacturing operations and design-for remanufacture. International Journal of Sustainable Engineering, 2(2), 91-102. http://dx.doi.org/10.1080/19397030902953080

Ijomah, W. L., McMahon, C. A., Hammond, G. P., \& Newman, S. T. (2007a). Development of robust design-forremanufacturing guidelines to further the aims of sustainable development. International Journal of Production Research, 45(18-19), 4513-4536. http://dx.doi.org/ 10.1080/00207540701450138

Ijomah, W. L., McMahon, C., Hammond, G., \& Newman, S. (2007b). Development of design for remanufacturing guidelines to Support sustainable manufacturing. Robotics and Computer Integrated Manufacturing, 23(6), 712-719. http://dx.doi.org/10.1016/j.rcim.2007.02.017.

Ilgin, M. A., \& Gupta, S. M. (2012). Remanufacturing Modelling and Analysis. Boca Raton Florida, CRC Press.

Jayaraman, V. (2006). Production planning for closed-loop supply chains with product recovery and reuse: an analytical approach. International Journal of Production Research, 44(5), 981-998. http://dx.doi.org/10. 1080/00207540500250507.

Katun Corporation. (2014). Information retrieved from http://www.katun.com/ap/wp-content/uploads/2011/05/ 5031_HP_Color_TNR_PL.pdf

Kim, H.-J., Skerlos, S., Severengiz, S., \& Seliger, G. (2009). Characteristics of the automotive remanufacturing enterprise with an economic and environmental evaluation of alternator products. International Journal of Sustainable Manufacturing, 1(4), 437-449. http://dx.doi.org/10.1504/IJSM.2009.031363

King, A., Miemczyk, J., \& Bufton, D. (2006). Photocopier remanufacturing at Xerox UK: A description of the process and consideration of future policy issues. In D. Brissaud et al. (Eds.), Innovation in Life Cycle Engineering and Sustainable Development (pp. 173-186). Springer. Printed in Netherlands

Kumar, N., Guide Jr, V. D. R., \& Van Wassenhove, L. N. (2002). Managing product returns at Hewlett, Packard, teaching case 05/2002-4940, INSEAD. 
Kumar, V. V., Liou, F. W., Balakrishnan, S. N., \& Kumar, V. (2013). Economical impact of RFID implementation in remanufacturing: a Chaos-based Interactive Artificial Bee Colony approach. Journal of Intelligent Manufacturing. http://dx.doi.org/10.1007/s10845-013-0836-9.

Lebreton, B., \& Tuma, A. (2006). A quantitative approach to assessing the profitability of car and truck tire remanufacturing. International Journal of Production Economics, 104(2), 639-652. http://dx.doi.org/10. 1016/j.ijpe.2004.11.010.

Lu, Q., Goh, M., Garg, M. \& Souza, R. D. (2014). Remanufacturing in Asia: location choice and outsourcing. International Journal of Logistics Management, 25(1), 20 - 34. http://dx.doi.org/10.1108/IJLM-10-20120125.

Lund, R. T. \& Hauser, W. M. (2003). Remanufacturing - An American Perspective. Retrieved from http://www.reman.org/Papers/ICRM\%20APRA\%20version.pdf

Lund, R. T. (1984a). Remanufacturing: The experience of the United States and implications for developing countries. World Bank Technical Paper, 31.

Lund, R. T. (1984b). Remanufacturing. Technology Review 87, 18(8).

Matsumoto, M., \& Ijomah, W. (2013). Remanufacturing. In J. Kauffman, \& K. M. Lee (Eds.), Handbook of Sustainable Engineering. http://dx.doi.org/10.1007/978-1-4020-8939-8-93.

Mti. (2014). Retrieved from http://www.mti.net.my/remanufacturingworkflow

Osibanjo O., \& Nnrom, I. C. (2008). Material Flows of Mobile Phones and Accessories in Nigeria: Environmental Implications and Sound End-of-Life Management Options. Environmental Impact Assessment Review, 28, 198-213. http://dx.doi.org/10.1016/j.eiar.2007.06.002.

Ovchininnikov, A., (2011). Revenue and Cost Management for Remanufactured Products. Production and Operations Management, 20(6), 824-840. http://dx.doi.org/ 10.1111/j.1937-5956.2010.01214.x.

Robert Bosch LLCBosch. (2014, June 23). Retrieved June 23, 2014 from http://www.boschautoparts.com/ Pages/default.aspx

Schau, E. M., Traverso, M. \& Finkbeiner, M. (2012). Life cycle approach to sustainability assessment: a case study of remanufactured alternators. Journal of Remanufacturin, 2(5). http://www.journalofremanufacturing. com/content $/ 2 / 1 / 5$.

Schulz, T., \& Ferretti, I. (2011). On the alignment of lot sizing decisions in a remanufacturing system in the presence of random yield. Journal of Remanufacturing, 1(3). http://dx.doi.org/10.1186/2210-4690-1-3.

Seitz, M. A. (2007). A critical assessment of motives for product recovery: the case of engine remanufacturing. Journal of Cleaner Production, 15(11-12), 1147-115. http://dx.doi.org/ 10.1016/j.jclepro.2006.05.029

Souza, G. C., \& Ketzenberg, M. E. (2002). Two-stage make-to-order remanufacturing with service-level constraints. International Journal of Production Research, 40(2), 477-493. http://dx.doi.org/10.1080/00207 540110090920.

Srivastava, R. (2004). Reusing Single Use Devices in Hospitals: A Case Study. In G. M. Surendra (Eds), Environmentally Conscious Manufacturing III, Proceedings of SPIE Vol. 5264 (1-5). SPIE, Bellingham, WA.

Steinhilper, R. (1998). Remanufacturing: The ultimate form of recycling. Stuttgart: Fraunhofer IRB Verlag, D-70569.

Stryker Sustainability Solutions. (2014). Retrieved from http://sustainability.stryker.com/how-it-works/devicereprocessing

Sundin, E., \& Bras, B. (2005). Making functional sales environmentally and economically beneficial through product remanufacturing. Journal of Cleaner Production, 13(9), 913-925. http://dx.doi.org/10.1016/j.jclepro. 2004.04.006

Sundin, E., \& Dunbäck, O. (2013). Reverse logistics challenges in remanufacturing of automotive mechatronic devices. Journal of Remanufacturing, 3(2). http://dx.doi.org/10.1186/2210-4690-3-2

Sundin, E., \& Lee, H. M. (2012). In what way is remanufacturing good for the environment? In Design for Innovative Value Towards a Sustainable Society: Proceedings of EcoDesign 2012: 7th International Symposium on Environmentally Conscious Design and Inverse Manufacturing (552-557). New York: Springer. 
United States International Trade Commision. (2012). Remanufactured Goods: An Overview of the U.S. and Global Industries, Markets and Trade. Retrieved from http://www.usitc.gov/publications/332/pub4356.pdf

Warsen, J., Laumer, M., \& Momberg, W. (2011). Comparative life cycle assessment of remanufacturing and new manufacturing of a manual transmission. In J. Hesselbach, \& C. Herrmann (Eds.), Glocalized Solutions for Sustainability in Manufacturing (67-72). Berlin, Heidelberg: Springer.

Zikopoulos, C. (2012). Remanufacturing lot-sizing under alternative perceptions of returned units' quality. Int. Journal of Business Science and Applied Management, 7(3).

Zussman, E., \& Seliger, G. (1999). Product Remanufacturing. In Shimon Y. Nof (Eds), Handbook of Industrial Robotics (2nd ed., pp. 1037-1043), New York: Wiley \& Sons.

\section{Copyrights}

Copyright for this article is retained by the author(s), with first publication rights granted to the journal.

This is an open-access article distributed under the terms and conditions of the Creative Commons Attribution license (http://creativecommons.org/licenses/by/3.0/). 